\title{
Hereditary Endometrial Carcinoma
}

\author{
J. Salvador Saldivar \\ Texas Tech University Health Sciences Center \\ Department of Obstetrics \& Gynecology, \\ Division of Gynecology Oncology, El Paso, Texas
}

USA

\section{Introduction}

Cancer of the uterine endometrium is the most common gynecologic malignancy diagnosed in women of the United States. It is estimated that in 2011, there will be 46,470 new endometrial cancers and 8,120 deaths due to this malignancy (American Cancer Society, 2011). The lifetime risk of developing endometrial cancer is approximately $3 \%$ in the general population. In Western countries, lifestyle changes and environmental factors play an important role in the carcinogenesis of endometrial cancer; however, there exist a proportion of cases in which an inherited predisposition increases this risk. In this chapter, hereditary nonpolyposis colorectal cancer syndrome or more commonly, Lynch Syndrome, will be reviewed and its association with endometrial cancer detailed.

\section{Lynch syndrome: Definition and clinical features}

Lynch syndrome (LS) or hereditary nonpolyposis colorectal cancer (HNPCC) is an autosomal-dominant hereditary cancer syndrome that predisposes carriers to multiple malignancies. It is caused by germline mutations in specific genes that participate in DNA mismatch repair (MMR), these include MLH1, MSH2, MSH6, PMS2, and most recently, EPCAM (Kupier et al., 2011; Lynch et al., 2003). As the name implies, colorectal cancer (CRC) traditionally has been perceived as the dominant malignancy with a lifetime risk of $43-48 \%$ for carriers, however, women with LS have an equal or greater lifetime risk of endometrial cancer (EC) (Stoffel et al., 2009). Further, in more than half of cases, women present with a gynecological cancer as their first or "sentinel" malignancy (Lu et al., 2005). For LS families, extracolonic cancers also include ovarian, stomach, upper urologic tract, small bowel, pancreas, hepato-biliary, brain (Turcot variant) and sebaceous adenomas/carcinomas (MuirTorre variant) (Lynch et al., 2003). This predisposition for other cancers has led to the use of Lynch Syndrome instead of HNPCC. It is also important to distinguish between Lynch I, in which colon cancer is the only contracted cancer, from Lynch II, where there exists other extracolonic cancers in the familial syndrome. In addition, some authors have reported a Lynch III as an appropriate name for identifying individuals with constitutively compromised MMR associated with biallelic mutations as seen with the Turcot and MuirTorre variants (Felton et al., 2007). 


\subsection{Clinical characteristics}

Current population estimates are that approximately 1 in 300 to 1 in 500 people carry a LS mutation making it similar in prevalence to Hereditary Breast and Ovarian cancer syndrome (Antoniou et al., 2000). These MMR mutations are inherited in an autosomal dominant manner and first-degree relatives have a 50\% chance of inheriting the LS-related cancers (Hampel et al., 2005). Women who inherit LS-associated germline mutations have a greatly increased risk of developing a gynecologic cancer. Further, among women with LS who develop two primary cancers, over $50 \%$ are diagnosed with a gynecologic cancer before colon cancer ( $\mathrm{Lu}$ et al., 2005). The range of risk for EC in women with LS is $27-71 \%$ compared with $3 \%$ in the general population and this risk varies with the specific MMR gene(s) involved, which will be discussed below (Koornstra et al., 2009).

The suspicion of a LS mutation should be raised among women diagnosed with EC at younger ages. The mean age range of EC in women with LS is 46 to 54 years, compared to 60 years in sporadic EC (Boks et al., 2002; Hampel et al., 2006). In a study by Lu et al., of 100 women with EC under age 50, $9(9 \%)$ were found to have identifiable mutations in the MMR genes MLH1, MSH2 and MSH6 (Lu et al., 2007). In another study that included 69 women with LS, EC was diagnosed under the age 40 in 18\% of their cohort (Schmeler et al., 2006).

Currently, there is no evidence to suggest that LS-associated EC portends a better or worse prognosis in patients when compared to sporadic EC. In fact, the majority of LS endometrial cancers are diagnosed in early stages, and like their sporadic counterparts, carry a favorable prognosis (Boks et al., 2002; Vasen et al., 1994). A case-control study of 50 women with LSassociated EC matched to 100 controls with sporadic EC for age and stage, found similar 5year cumulative survival rates, $88 \%$ vs. $82 \%$, respectively $(\mathrm{P}=0.59)$ (Boks et al., 2002). In another series of 125 women with clinically defined HNPCC, the overall survival rate for patients diagnosed with EC was high, with only $12 \%$ of patients succumbing to their disease (Vasen et al., 1994). A large study comparing the pathological features of sporadic EC to that of 50 patients with LS found that $78 \%$ were diagnosed as stage I, $10 \%$ were stage II, and $12 \%$ were stage III/IV in the LS cohort. Deep myometrial involvement was noted in $26 \%$ of cases, while lymphvascular space involvement was seen in $24 \%$. However, when the LS cases were compared to the sporadic EC cases, stage, myometrial invasion, and lymphvascular space involvement were not statistically significantly different (Broaddus et al., 2006).

\subsection{Histopathologic characteristics}

Like sporadic endometrial cancer, the majority of LS-associated histology is of the endometrioid variety. However, studies evaluating the histologies of endometrial tumors in patients with LS have reported a wide variety of non-endometrioid types, including papillary serous carcinoma, clear cell carcinoma, malignant mixed Mullerian and neuroendocrine tumors (Broaddus et al., 2006; Carcangiu et al., 2010). For example, a small study of six LS-related endometrial cancers found significantly more often, poorly differentiated ( $83 \%$ versus $27 \%$ ), presence of a Crohn-like lymphoid reaction (100\% versus $13 \%)$, lymphangio-invasive growth (67\% versus $0 \%)$, and high number of tumor-infiltrating lymphocytes $(100 \%$ versus $36 \%$ ), when compared with sporadic ECs (van den Bos et al., 2004). As mentioned previously, there is no evidence of a significant survival advantage or disadvantage associated with LS-related endometrial cancer (Boks et al., 2002).

Conversely, tumor location appears to differ between sporadic and LS-associated endometrial cancer. Although the majority is commonly found in the uterine corpus, 
endometrial cancer in the lower uterine segment (LUS) appears to have a strong association with Lynch syndrome. One study that included over 1000 patients with EC, found the prevalence of LS in patients with LUS tumors (10 of 35 or $29 \%$ ) to be much greater than that of the general EC patient population (Westin et al., 2008). On the basis of this finding, the authors recommend that LS should be considered in all women with LUS tumors.

\section{Lynch syndrome: Mechanisms of carcinogenesis}

Six variants of the mismatch repair gene (MMR) have been cloned: MSH2 (MutS homolog 2, chromosome 2p16), MLH1 (MutL homolog 1, chromosome 3p21), MSH3 (MutS homolog 3, interacts with MLH1), MSH6 (MutS homolog 6, chromosome 2p16), PMS1 (postmeiotic segregation 1, chromosome 2q31) and PMS2 (postmeiotic segregation 2, chromosome 7p22) (Koessler et al., 2008). However, germline mutation analysis in four of these DNA-MMR genes (MLH1, MSH2, MSH6, and PMS2) is confirmatory diagnosis for LS (Hampel et al., 2005). A fifth and most recently identified gene, EPCAM (previously TACSTD1), is not a mismatch repair gene; however, large deletions in the $3^{\prime}$ end in the upstream EPCAM gene affect $M S H 2$. This occurs by transcriptional read-through into and subsequent epigenetic silencing of its downstream neighbor, $M S H 2$, resulting in the LS phenotype (Ligtenberg et al., 2009).

The role of the MMR machinery is to maintain genomic integrity by correcting base-pair and small insertion-deletion mismatches that are generated during DNA replication. Two heterodimeric protein complexes, MutS- $\alpha$ and MutS- $\beta$, recognize the mismatch. MutS- $\alpha$ is a heterodimer of $\mathrm{MSH} 2$ and MSH6 proteins and MutS- $\beta$ is an MSH2/MSH3 heterodimer, see Figure 1 (Masuda et al., 2011). Either MutS- $\alpha$ and MutS- $\beta$ heterodimers can recognize insertion/deletion loops with more than two bases, but MutS- $\alpha$ preferentially recognizes single base-pair mismatches or, one or two base pair insertion-deletion loops (Koessler et al., 2008). The repair components of the MMR machinery involve three other heterodimer pairs:

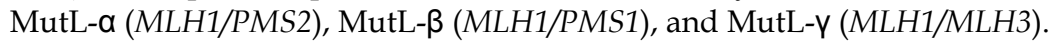

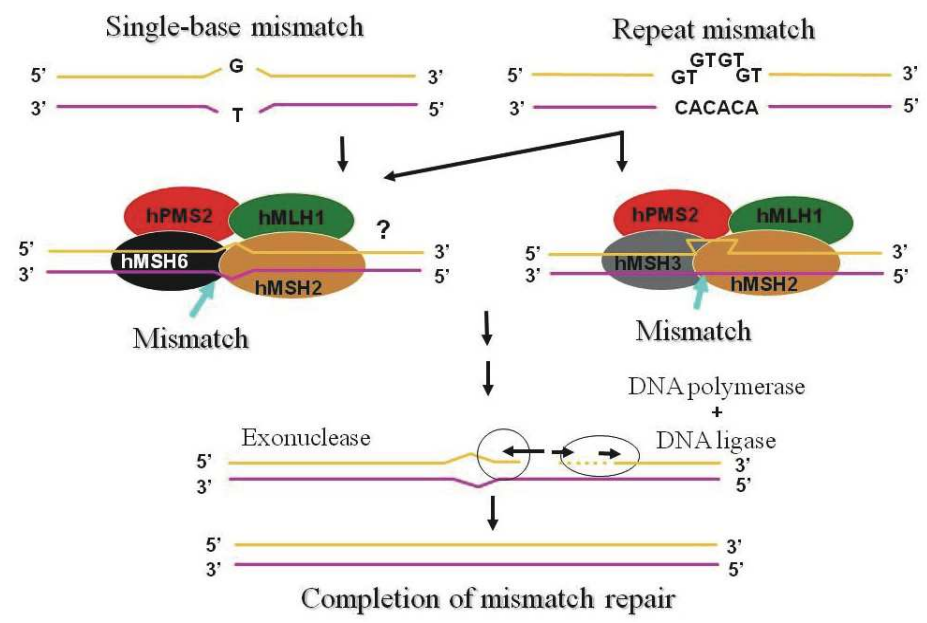

(Reproduced from Masuda et al., 2011).

Fig. 1. The DNA Mismatch Repair (MMR) machinery in humans. 
In general, affected patients with LS carry a germline mutation in one allele of a MMR gene and acquire a second mutation within the tumor. Common mechanisms of the "second hit" include allele inactivation by mutation, loss of heterozygosity, or promoter hypermethylation leading to epigenetic silencing. Biallelic inactivation of MMR genes results in genomic instability due to failure in the repair of base pair mismatches that occur commonly during DNA replication (approximately 1 in $10^{6}$ base pairs). DNA mismatches commonly occur in regions of tandem repeats of short DNA sequences called microsatellites that make up about $3 \%$ of human DNA (Baudhuin et al., 2005). Normally, the MMR machinery corrects errors in microsatellites, but mutations in the MMR genes in tumors cause expansion or contraction of these regions compared to normal tissue. These genetic alterations in microsatellite length are termed "microsatellite instability" (MSI) and are the molecular signature of LS-associated cancers (Lynch et al., 2009). Further, the increased mutation rate that results from MMR loss leads to alterations in nucleotide repeats in many other pathways; those that control cell growth, regulate cell death, and in the MMR genes themselves. Together, this accumulation of mutations drives the carcinogenetic process in LS.

\subsection{MMR genes and the risk of endometrial cancer}

The range of cancer risks in LS varies depending on the MMR gene involved. Approximately $70-80 \%$ of the clinical features of LS are accounted for by MLH1 and MSH2 mutations. Families with MSH6 and PMS2 mutations appear to have an attenuated cancer phenotype, presenting with a later age of diagnosis and a lower penetrance than MLH1 and MSH2. MSH6 may account for up to $15 \%$ and PMS2 for up to $3-15 \%$ of all identified LS mutations (Hampel et al., 2005; Niessen et al., 2009). Recently, EPCAM has been thought to account for approximately 1-3\% of LS mutations (Kuiper et al., 2011).

Endometrial cancer risk per MMR gene is as follows:

MLH1 and MSH2: Endometrial cancer in patients with MLH1 and MSH2 mutations often occur before the age of 50 . The risk in MLH1 and MSH2 carriers is up to $20 \%$ by age 50 and up to $60 \%$ by age 70 according to some studies (Aarnio et al., 1999; Lynch et al., 2009). However, the diagnosis of EC after the age of 50 should still raise concern for LS if there is a positive family history.

MSH6: MSH6 mutation carriers appear to have the highest risk for endometrial cancer (up to $71 \%$ ) of the MMR genes, higher than that of colorectal cancer (CRC) (Hendricks et al., 2004). The average age of onset of EC in MSH6 mutation-positive individuals is 54 years. One study identified a somewhat lower risk for endometrial cancer in MSH6 mutation carriers, however the risk was significantly increased above the general population, and appeared to be higher than the risk for CRC in women with LS. They reported a risk for endometrial cancer to age 70 of $26 \%$ (95\% CI: 18-36\%) and risk to age 80 of $44 \%$ (95\% CI: 30 $58 \%$ ) (Baglietto et al., 2009). These reports suggest that if a woman carries an MLH1, MSH2 or MSH6 mutation, her risk of EC may be even higher than her risk of CRC.

PMS2: One large series of PMS2 carriers found the incidence of EC to be 7.5-fold higher than expected in the general population. This translates to a $15 \%$ risk to age 70 (Senter et al., 2008).

EPCAM: The clinical features of EPCAM/TACSTD1 mutations as a cause of Lynch syndrome is still being defined. Recent studies evaluating EPCAM $3^{\prime}$-end mutation carriers for their clinical phenotype found the risk for EC was dependent upon the type and size of 
EPCAM mutation (Kempers et al., 2011; Kupier et al., 2011). However, since deletions in EPCAM lead to disruption of the $M S H 2$ gene, following management guidelines for LS appears prudent at this point. Further research is needed to clarify the EC risks associated with EPCAM mutations and their association with LS.

\subsection{Microsatellite instability}

As discussed above, microsatellite instability (MSI) results from defects in the MMR machinery that correct the replication errors found in these regions of the human genome. MSI may occur via two mechanisms. MSI in the majority of EC is sporadic in nature, resulting from hypermethylation of the $M L H 1$ promoter leading to epigenetic silencing of the gene (Esteller et al., 1998). The second, and the one associated with LS, is a consequence of germline mutations in the DNA-MMR genes as discussed above. Thus, MSI is not pathognomonic of LS, and in fact, LS accounts for only a minority of MSI-high EC cases (Meyer et al., 2009).

MSI analysis may be performed on paraffin-embedded tissue sections. Amplification by PCR using five primers recommended by the National Cancer Institute-two mononucleotide (BAT25, BAT26) and three dinucleotide repeats (D2S123, D5S346, D173250)-are used to detect changes in the number of microsatellite repeats in tumor compared with normal tissue (Boland et al., 1998). Tumors are classified using the five marker panel as follows: MSI-high (MSI-H, highly unstable) if two or more of the five markers are positive, MSI-low (MSI-L, low instability) if one of the markers is positive, and MS-stable (MS-S, no instability) if none of the markers show MSI. MSI analysis has some limitations when used to detect LSassociated endometrial cancers. Many, but not all the ECs that are diagnosed in LS are MSIH, while most, but not all MSI-H endometrial cancers are sporadic (Garg \& Soslow, 2009). Thus, MSI analysis may fail to detect some LS-associated ECs, while it may turn out positive in a large percentage of sporadic ECs.

\subsection{Immunohistochemistry}

Mutations in the MMR genes typically result in truncated or absent protein products. Immunohistochemistry (IHC) staining using antibodies to the C-terminus of the MMR proteins can be used to identify LS-associated tumors for the absence of these gene products (Weissman et al., 2011). Like CRC, IHC in endometrial cancer has shown efficacy for identification of LS. However, results must be interpreted with caution since both absent MMR gene product and MLH1 promoter hypermethylation are found in up to one-third of endometrioid adenocarcinomas (Modica et al., 2007).

Further, more than one gene product may be absent. This may be due to the heterodimerization of the MMR proteins. Thus, a loss in MLH1 staining is almost always coupled with concurrent loss of PMS2, and loss of MSH2 staining is accompanied by loss of MSH6. A deleterious mutation in either primary proteins MLH1 and MSH2 will most likely result in loss of the entire heterodimer (Wei et al., 2002). As an example, a lack of tumor staining for MLH1 and PMS2 is most likely the result of MLH1 protein absence. In contrast, PMS2 and MSH6 are secondary proteins, and a deleterious mutation in either gene will result in loss of that isolated protein. In addition, large deletions in the upstream EPCAM gene can cause inactivation and absence of $M S H 2$ expression by IHC. As many as $20-25 \%$ of cases suspected of having a mutation in $\mathrm{MSH} 2$, are actually caused by germline deletions in EPCAM (Rumilla et al., 2011) 
Assays to detect methylation of the MLH1 promoter that can recognize epigenetic mechanisms that lead to MSI-H, should be considered along with IHC for MMR gene testing (Whelan et al., 2002). For example, studies have shown that methylation of the small proximal region in the $M L H 1$ promoter located -248 to -178 relative to the gene transcription start site invariably correlates with loss of MLH1 expression (Kang et al., 2002). If methylation is present, the patient most likely has sporadic tumor rather than LS-associated carcinoma.

IHC has been shown to be a convenient and readily performed test for the detection of germline MMR gene mutations. There are, however, studies of mutations in the MMR genes that are not detected by IHC (Vasen et al., 2004). In fact, by most reports, there is an approximate $5-10 \%$ false negative rate with both IHC and MSI. That is, up to $90-95 \%$ of CRCs and ECs seen in LS patients are MSI-H or lack at least one MMR protein product on IHC testing (Ferreira et al., 2009). Therefore, most experts recommend that IHC and MSI testing in combination, along with family and personal history, be used to maximize identification of patients at risk for LS so that germline genetic testing may confirm the diagnosis.

\section{Identifying patients at risk for Lynch syndrome}

In 1991, the International Collaborative Group on Hereditary Nonpolyposis Colorectal Cancer established research criteria, which became known as the Amsterdam Criteria (AC I), for the diagnosis of LS (Vasen et al., 1991). These criteria were broadened in 1999 as the Amsterdam Criteria II (AC II) to recognize a diagnostic role for extra-colonic tumors and suggested that LS-associated cancers should be suspected in relatives (Vasen et al., 1999) (see Table 1).

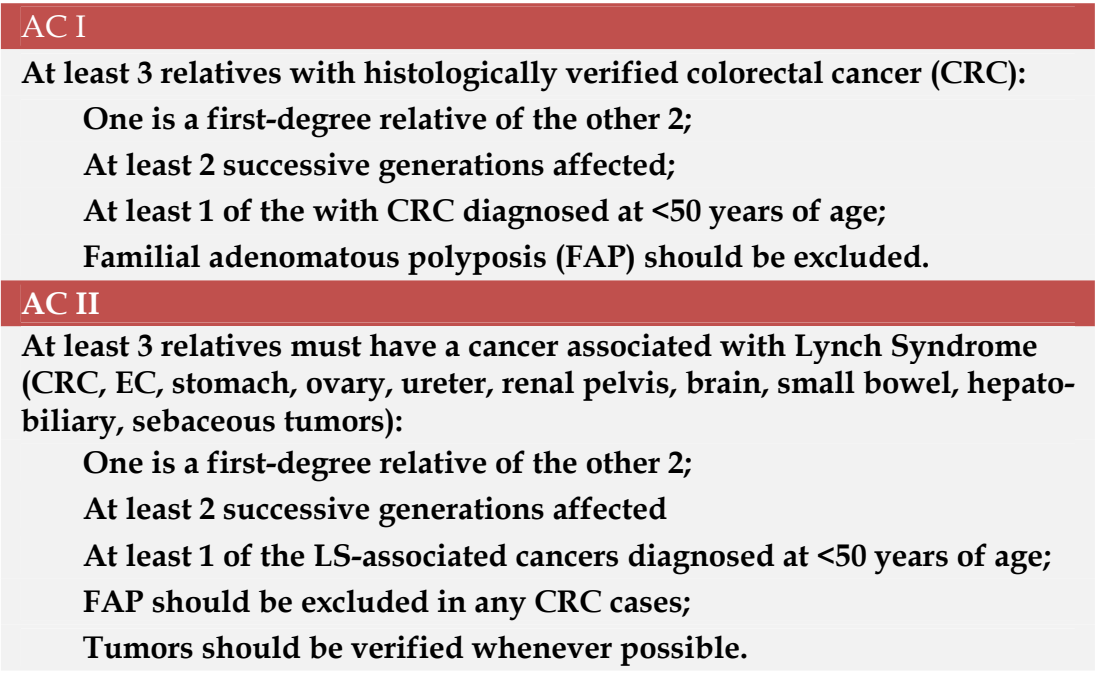

(adapted from Vasen et al., 1991 \& Vasen et al., 1999).

Table 1. Amsterdam Criteria I and II. 
Individuals meeting the AC I were presumptively defined as having LS. However, once MSI analyses and genetic testing became available, it became clear that certain families who met AC II criteria did not have an identifiable MMR germline mutation (Lindor et al., 2005). In fact, approximately half of patients with LS will be missed by these criteria and approximately half will meet the criteria and not have LS ie., do not carry MSI or MMR variations; but a high familial risk of uncertain etiology. The term "familial colorectal cancer type $X^{\prime \prime}$ has been suggested for these patients to distinguish them from those with LS (Lindor et al., 2005).

As a result of this major limitation of the $\mathrm{AC}$, the Bethesda Guidelines were originally developed (1997) and revised (2004) to help identify patients with CRC or other LSassociated cancers who should be screened for MSI (Umar et al., 2004). If found to have microsatellite unstable cancers, these patients should undergo subsequent germline MMR genetic testing (see Table 2).

\section{Tumors from individuals should be tested for MSI if:}

CRC $^{1}$ diagnosed in a patient who is $<50$ years of age;

Presence of synchronous, or metachronous LS-associated tumors ${ }^{2}$, regardless of age; CRC with MSI-H histology ${ }^{3}$ diagnosed in a patient who is $<60$ years of age; CRC diagnosed in a patient with 1 or more first-degree relatives with an LSassociated cancer ${ }^{2}$, with one of the cancers being diagnosed under 50 years of age; CRC diagnosed in a patient with 2 or more first- or second-degree relatives with LS-associated cancers ${ }^{2}$ regardless of age.

(adapted from Umar et al., 2004 and NCCN Guidelines Version 2.2011).

${ }^{1}$ Endometrial cancer $<50$ years of age is not included in the guidelines, however, current evidence suggests that these individuals should be evaluated for LS.

${ }^{2}$ LS-associated cancers include: CRC, EC, stomach, ovarian, ureter/renal pelvis, pancreas, hepatobiliary tract, brain (glioblastomas as seen in Turcot syndrome), small bowel, sebaceous adenomas and keratoacanthomas (seen in Muir-Torre syndrome).

${ }^{3}$ Presence of tumor infiltrating lymphocytes, Crohn's-like lymphocytic reaction, mucinous (signet-ring) differentiation, or medullary growth pattern.

Table 2. Revised Bethesda Guidelines.

Despite the revised Bethesda criteria, multiple studies show the guidelines have low specificity, with approximately $80 \%$ of individuals who meet the criteria will not have LS (Hampel et al., 2005, 2006). Concerns that both the AC and Bethesda guidelines may miss a substantial portion of patients with LS, most investigators agree that all CRC cases be screened for MSI and that any case identified as MSI-H and/or show absence of $\geq 1$ MMR protein, undergo further genetic testing for LS (EGAPP recommendations, 2009). Further, even with normal MSI and IHC, it is important to consider both the patient and their family history when determining to proceed with germline testing for LS.

While it appears that these guidelines focus on CRC patients, it is important to know that they are at high risk of developing a synchronous or metachronous cancers, especially of the colon, rectum, endometrium and/or ovary (Lu et al., 2005; Lynch et al., 1977; Mecklin \& Jarvinen, 1986; Watson et al., 2001). An early study found that among 33 families with "cancer family syndrome", the risk of a second LS-associated cancer was approximately $30 \%$ within 10 years of the initial cancer diagnosis and up to $50 \%$ within 15 years of the initial cancer diagnosis (Mecklin \& Jarvinen, 1986). Another report found the annual metachronous 
CRC rates to be $2.1 \%$ and $1.7 \%$ between $M L H 1$ and $M S H 2$ families, respectively, as compared to $0.33 \%$ for the general population (Lin et al., 1998). In a study by Lu et al., dual primary cancers (CRC and gynecologic-endometrial or ovarian) were reported in 16 women $(14 \%)$ of 117 women with LS (Lu et al, 2005). An earlier study found synchronous and metachronous cancers: endometrial (21 patients), CRC (28 patients), and either gastric, small bowel, or urinary tract cancers (6 patients), in 80 women with LS-associated ovarian cancer (Watson et al., 2001).

The Society of Gynecologic Oncologists Education Committee published guidelines to identify women with a personal or family history of EC or ovarian cancer, and synchronous or metachronous CRC, whom may benefit from genetic risk assessment for LS (Lancaster et al., 2007) (see Table 3).

\begin{tabular}{|l|l|}
\hline $\begin{array}{l}\text { Genetic risk assessment RECOMMENDED: } \\
\text { Patients with }>20-25 \% \text { chance of } \\
\text { having LS }\end{array}$ & $\begin{array}{l}\text { Genetic risk assessment may be HELFUL: } \\
\text { Patients with }>5-10 \% \text { chance of } \\
\text { having LS }\end{array}$ \\
\hline $\begin{array}{l}\text { EC or ovarian cancer with a synchronous or } \\
\text { metachronous CRC with the first cancer } \\
\text { diagnosed < age 50; }\end{array}$ & $\begin{array}{l}\text { EC or ovarian cancer with synchronous or } \\
\text { metachronous CRC or other LS-associated } \\
\text { cancers* with the first cancer diagnosed at } \\
\text { any age; }\end{array}$ \\
\hline EC or CRC and meet AC II criteria; & EC or CRC diagnosed < age 50; \\
\hline $\begin{array}{l}\text { First or second-degree relative with a known } \\
\text { germline mutation in a MMR gene. }\end{array}$ & $\begin{array}{l}\text { EC or CRC with } 2 \text { or more first or second- } \\
\text { degree relatives with LS-associated } \\
\text { cancers; }\end{array}$ \\
\hline & $\begin{array}{l}\text { First or second-degree relative that meets } \\
\text { the above criteria. }\end{array}$ \\
\hline
\end{tabular}

(adapted from Lancaster et al., 2007).

"LS-associated cancers include: CRC, EC, stomach, ovarian, ureter/renal pelvis, pancreas, hepatobiliary tract, brain (glioblastomas as seen in Turcot syndrome), small bowel, sebaceous adenomas and keratoacanthomas (seen in Muir-Torre syndrome).

Table 3. Society of Gynecologic Oncologist: Guidelines for Lynch Syndrome Risk Assessment.

\section{Managing Lynch syndrome cancer risks}

Any discussion with individuals and family members at risk for hereditary cancer must occur in the context of a high risk cancer clinic with available medical interventions or referral made to address these risks. The benefits and limitations of surveillance and risk reducing surgery should be individualized, and when possible, evidence based. Over the past few years, a number of studies and recommendations have been published that document the available strategies to guide management of these at-risk individuals with LS (Lindor et al., 2006; NCCN Practice Guidelines 2011; Schmeler et al., 2006; Winawer et al., 2003).

\subsection{Surveillance}

Both EC and ovarian cancer are likely to develop before the menopause in women diagnosed with LS. Endometrial cancer screening in women with LS who are asymptomatic consists of annual endometrial sampling beginning at age 30 to 35 or five to ten years prior 
to the earliest age of the family member diagnosed with a LS-associated cancer (Lindor et al., 2006; NCCN Practice Guidelines 2011). A recent Finnish study evaluated the efficacy of screening with endometrial biopsy and transvaginal ultrasound (TVUS) among 175 mutation-positive women age 35 or older with LS (Renkonen-Sinisalo et al., 2007). They found that surveillance intrauterine biopsy detected 8 women with EC and 4 ECs were indicated by TVUS. Although no statistically significant differences were observed in cancer stage or survival when compared with 83 women with EC who did not undergo surveillance, this strategy detected earlier cancers and there were no deaths in the surveillance group.

Studies have shown that endometrial thickness measurement to detect EC has a high falsepositive rate in women with LS, and in particular premenopausal women where endometrial thickness is highly variable (Dove-Edwin et al., 2002). Conversely, in postmenopausal women, atypical endometrial thickness is less variable. In this population, TVUS and endometrial sampling have similar sensitivities, and early detection is common because most women present with abnormal uterine bleeding (Dijkhuizen et al., 2000).

The primary role of TVUS appears to be in ovarian cancer screening in women with LS. LS is associated with an increased risk of ovarian cancer, estimated at $12 \%$ by age 70 compared with $1.5 \%$ in the general population (Barrow et al., 2009). Although there are no data regarding ovarian cancer screening in women with LS, most experts recommend an annual pelvic exam, TVUS, and CA125 serum tumor marker, every 6 to 12 months, starting at age 30 to 35 or five to ten years prior to the earliest age of the family member diagnosed with a LS-associated cancer (Lindor et al., 2006; NCCN Practice Guidelines 2011). Since ovarian cancer is much less common than EC in women with LS, it is unknown whether these screening strategies decrease morbidity and mortality.

Although not the emphasis of this chapter, CRC surveillance recommendations in individuals with LS include, colonscopy every one to two years, beginning at age 20 to 25 or two to five years prior to the earliest diagnosis if it is before age 25 (Lindor et al, 2006; NCCN Practice Guidelines 2011). For MSH6 and PMS2 mutation positive carriers, colonoscopy is recommended at age 30 to 35 or 10 years prior to the youngest age of diagnosis in the family, whichever comes first (NCCN Practice Guidelines 2011; Senter et al., 2008). In support of this strategy, one study showed that colonoscopy every 3 years reduced the CRC risk by $50 \%$ and decreased overall mortality by about $65 \%$ (Jarvinen et al., 2000). In a further study, the cumulative risk of CRC after a 10-year follow-up was 6\% with a surveillance interval of 1-2 years compared to a 2-3 year surveillance (Vasen et al., 2010).

Lynch syndrome is associated with an increased risk for other cancers as well, including, gastric, small bowel, urothelial, pancreatic, and brain. It is imperative that the clinician caring for these individuals and their families with LS, refer to the National Comprehensive Cancer Network (NCCN) Guidelines for management options for these cancer risks.

\subsection{Risk reducing surgery}

Women with LS may consider prophylactic hysterectomy and bilateral salpinooophorectomy (BSO) to substantially reduce the risk of endometrial and ovarian cancers (Guillem et al., 2006; NCCN Practice Guidelines 2011). In a large retrospective case-control study of 315 mutation-positive (MLH1, MSH2, or MSH6) women, risk-reducing hysterectomy with BSO proved to be an effective strategy for preventing endometrial and ovarian cancer (Schmeler et al., 2006). No women who had a hysterectomy developed EC 
compared with 69 of 210 (33\%) of the controls (no hysterectomy). Further, no women who underwent a BSO developed ovarian cancer compared with 12 of 233 (5\%) of the controls (no BSO). One ovarian cancer was diagnosed in a woman who underwent a hysterectomy. Risk-reducing surgery may take place at the time of CRC diagnosis or once child-bearing is completed. In addition, there are no recommendations for chemopreventive strategies in LS to decrease gynecologic cancer risks. Studies from Lu et al., suggest oral contraceptive pills or medroxyprogesterone acetate (Depo-Provera) may have the potential to prevent EC and/or ovarian cancer associated with LS (Lu et al., 2010).

Counseling regarding prophylactic surgery of this kind should include not only the risks inherent in surgery, but also premature menopause and its associated risks; menopausal vasomotor symptoms, estrogen therapy, osteoporosis, urogenital atrophy, and less clear, heart disease (Chen et al., 2007; Schmeler et al., 2006). Preoperative assessment should include colonoscopy, endometrial sampling, TVUS and a CA125 tumor marker. Preparation for a complete surgical staging should be available if occult carcinoma is found.

Cost-effectiveness decisions must be reviewed with the patient when embarking on a management strategy for surveillance or prevention of LS-associated cancers. One study compared different strategies in a hypothetical cohort of women with LS: 1) no prevention, 2) prophylactic hysterectomy and BSO at age 30,3) prophylactic surgery at age 40,4) annual screening with endometrial biopsy, TVUS and CA125 from age 30, and 5) annual screening from age 30 until prophylactic surgery at age 40 (combined strategy) (Kwon et al., 2008). The authors found that annual screening followed by prophylactic surgery at age 40 was the most effective gynecologic cancer prevention strategy, but the incremental benefit over riskreducing surgery alone came with a substantial cost. Thus, a careful review of different strategies to improve the effectiveness and decrease the lifetime costs of these interventions is warranted in patients with LS.

\section{Conclusion}

Lynch Syndrome (hereditary nonpolyposis colorectal cancer ) is an autosomal dominant disorder that is caused by germline mutations in one of several DNA-MMR genes (MLH1, MSH2, MSH6, PMS2, and EPCAM). The syndrome is characterized by an approximate lifetime risk of EC and CRC of $40 \%$ to $60 \%$ in affected individuals. Other LS-associated cancers (gastric, ovarian, urothelial, pancreas, hepatobiliary tract, brain, small bowel, skin) as well as, synchronous and metachronous cancers, may present in these patients and their families. Identification of these individuals meeting AC II and/or Bethesda guidelines should have their tumors tested for MSI and for MMR protein expression by IHC. Further genetic counseling and direct MMR gene testing of those at-risk individuals should be done in the context of an established high risk genetics/cancer clinic. Post-test genetic counseling regarding the risks and benefits of LS-associated cancer surveillance and prophylactic surgery strategies, should be performed with consideration of the informed consent, completed childbearing, autonomy, cost-effectiveness and quality of life, for each individual patient.

\section{References}

Aarnio M, Sankila R, Pukkala E, Salovaara R, Aaltoner LA, de la Chapelle A, Peltomaki P, Meclin JP, Jarvinen HJ. Cancer Risk in Mutation Carriers of DNA-Mismatch Repair Genes. International Journal of Cancer. 1999;81:214-18. 
American Cancer Society. (2011). Cancer Facts \& Figures 2011. Atlanta: American Cancer Society.

Antoniou AC, Gayther SA, Stratton JF, Ponder BAJ, Easton DF. Risk Models for Familial Ovarian and Breast Cancer. Genetic Epidemiology. 2000;18:173-90.

Baglietto L, Lindor NM, Dowty JG, White DM, Wagner A, Gomez Garcia EB, Vriends AH. Risks of Lynch Syndrome Cancers for MSH6 Mutation Carriers. Journal of the National Cancer Institute. 2009;102(3):193-201.

Barrow E, Robinson L, Alduaij W, Shenton A, Clancy T, Lalloo F, Hill J, Evans DG. Cumulative Lifetime Incidence of Extracolonic Cancers in Lynch Syndrome: A Report of 121 Families with Proven Mutations. Clinical Genetics. 2009;75:141-9.

Baudhuin LM, Burgart LJ, Leontovich O, Thibodeau SN. Use of Microsatellite Instability and Immunohistochemistry for the Identification of Individuals at Risk for Lynch Syndrome. Familial Cancer. 2005;4:255-265.

Boks DES, Trujillo AP, Voogd AC, Morreau H, Kenter GG, Vasen HFA. Survival Analysis of Endometrial Carcinoma associated with Hereditary Nonpolyposis Colorectal Cancer. International Journal of Cancer. 2002;102;198-200.

Boland RC, Thibodeau SN, Hamilton SR, Sidransky D, Eshleman JR, Burt RW, Meltzer SJ, Rodriguez-Bigas MA, Fodde R, Ranzani NG, Srivastava S. A National Cancer Institute Workshop on Microsatellite Stability for Cancer Detection and Familial Predisposition: Development of International Criteria for the Determination of Microsatellite Stability in Colorectal Cancer. Cancer Research. 1998;58:5248- 5257.

Broaddus RR, Lynch HT, Chen LM, Daniels MS, Conrad P, Munsell MF, White KG, Luthra R, Lu KH. Pathologic Features of Endometrial Carcinoma Associated with HNPCC: a Comparison with Sporadic Endometrial Carcinoma. Cancer. 2006;106(1):87-94.

Carcangiu M, Radice P, Casalini P, Bertario L, Merola M, Sala P. Lynch Syndrome Related Endometrial Carcinomas Show a High Frequency of Nonendometrioid Types and of High FIGO grade Endometrioid Types. International Journal of Surgical Pathology. 2010;18(1):21-6.

Chen LM, Yang KY, Little SE, Cheung MK, Caughey AB. Gynecologic Cancer Prevention in Lynch Syndrome/Hereditary Nonpolyposis Colorectal Cancer Families. Obstetrics E Gynecology. 2007;110:18-25.

Dijkhuizen FP, Mol BW, Brolmann HA, Heintz AP. The Accuracy of Endometrial Sampling in the Diagnosis of Patients with Endometrial Carcinoma and Hyperplasia: A Metaanalysis. Cancer. 2000;89:1765- 72.

Dove-Edwin I, Boks D, Goff S, Kenter GG, Carpenter R, Vasen HF, Thomas HJ. The Outcome of Endometrial Carcinoma Surveillance by Ultrasound Scan in Women at Risk of Hereditary Nonpolyposis Colorectal Carcinoma and Familial Colorectal Carcinoma. Cancer. 2002;94:1708-12.

Esteller M, Levine R, Baylin SB, Ellenson LH, Herman JG. MLH1 Promoter Hypermethylation is associated with the Microsatellite Instability Phenotype in Sporadic Endometrial Carcinomas. Oncogene. 1998;17:2413-7.

Evaluation of Genomic Applications in Practice and Prevention (EGAPP) Working Group. Recommendations from the Working Group: Genetic Testing Strategies in Newly Diagnosed Individuals with Colorectal Cancer Aimed at Reducing Morbidity and Mortality from Lynch Syndrome in Relatives. Genetics in Medicine. 2009;11(1):35-41. 
Felton KE, Gilchrist DM, Andrew SE. Constitutive deficiency in DNA mismatch repair: is it time Lynch III? Clinical Genetics. 2007;71:483-498.

Ferreira AM, Westers $\mathrm{H}, \mathrm{Wu} \mathrm{Y}$, Niessen RC, Olderode-Berends $\mathrm{M}$, van der Sluis $\mathrm{T}$, van der Zee AG, Hollema H, Kleibeuker JH, Simons RH, Hofstra RM. Do Microsatellite Instability Profiles Really Differ between Colorectal and Endometrial Tumors? Genes, Chromosomes \& Cancer. 2009;48:552-7.

Garg K and Soslow RA. Lynch Syndrome (Hereditary Non-polyposis Colorectal Cancer) and Endometrial Cancer. Journal of Clinical Pathology. 2009;62:679-684.

Guillem JG, Wood WC, Moley JF, Berchuck A, Karlan BY, Mutch DG, Gagel RF, Weitzel J, Morrow M, Weber BL, Giardiello F, Rodriguez-Bigas MA, Church J, Gruber S, Offit K. ASCO/SSO Review of Current Role of Risk-Reducing Surgery in Common Hereditary Cancer Syndromes. Journal of Clinical Oncology. 2006;24:4642-60.

Hampel H, Frankel WL, Martin E, Arnold M, Khanduja K, Kuebler P, Nakagawa H, Sotamaa K, Prior TW, Westman J, Panescu J, Fix D, Lockman J, Comeras I, de la Chapelle, A. Screening for Lynch Syndrome (Hereditary Nonpolyposis Colorectal Cancer). NEJM. 2005;352:1851-1860.

Hampel H, Frankel W, Panescu J, Lockman J, Sotamaa K, Fix D, Comeras I, Jeunesse JL, Nakagawa H Westman JA, Prior TW, Clendenning M, Penzone P, Lombardi J, Dunn P, Cohn DE, Coeland L, Eaton L, Fowler J, Lewandowski G, Vaccarello L, Bell J, Reid G, de la Chapelle A. Screening for Lynch Syndrome (Herediatary Nonpolyposis Colorectal Cancer) among Endometrial Cancer Patients. Cancer Research. 2006;66:7810.

Hendriks YM, Wagner A, Morreau H, Menko F, Stormorken A, Quehenberger F, Sandkuijl L, Moller P, Genuardi M, Houwelingen HV, Tops C, Puijenbroek MV, Verkuijlen P, Kenter G, Mil AV, Meijers- Heijboer H, Tan GB, Breuning MH, Fodde R, Winjen JT, Brocker-Vriends AHJT, Vasen H. Cancer Risk in Hereditary Nonpolyposis Colorectal Cancer due to MSH6 Mutations: Impact on Counseling and Surveillance. Gastroenterology. 2004;127:17-25.

Jarvinen HJ, Aarnio M, Mustonen H, Akatan-Collan K, Aaltonen LA, Peltomaki P, de la Chapelle A, Mecklin JP. Controlled 15-year Trial on Screening for Colorectal Cancer in Families with Hereditary Nonpolyposis Colorectal Cancer. Gastroenterology. 2000;118:829-34.

Kang GH, Lee S, Shim YH, Kim JC, Ro JY. Profile of Methylated CpG sites of hMLH1 Promoter in Primary Gastric Carcinoma with Microsatellite Instability. Pathology International. 2002;52(12):764-768.

Kempers M, Kuiper RP, Ockeloen CW, Chappuis PO, Hutter P, Rahner N, Schackert PHK, Steinke V, Holinski-Feder PE, Morak M, Kloor M, Buttner R, Verwiel ETP, Krieken JHV, Nagtegall ID, Goossens M, van der Post RS, Niessen RC, Sijmons RH, Kluijt I, Hogervorst FBL, Leter EM, Gille JJP, Aalfs CM, Redeker EJW, Hes FJ, Tops CMJ, van Nesselrooij BPM, van Gin ME, Gomez Garcia EB, Eccles DM, Bunyan DJ, Syngal S, Stoffel EM, Culver JO, Palomares MR, Graham T, Velsher L, Papp J, Olah E, Chan TL, Leung SY, van Kessel AG, Kiemeney LALM, Hoogerbrugge N, Ligtenberg MJL . Risk of Colorectal and Endometrial Cancer in EPCAM Deletion Positive Lynch Syndrome: a Cohort Study. Lancet Oncology. 2011;12:49-55. 
Koessler T, Oestergaard MZ, Song H, Tyrer J, Perkins B, Dunning AM, Easton DF, Pharoah PDP. Common Variants in Mismatch Repair Genes and Risk of Colorectal Cancer. Gut. 2008;57:1097.

Koornstra JJ, Mourits MJE, Sijmons RH, Leliveld AM, Hollema H, Kleibeuker JH. Management of Extracolonic Tumors in Patients with Lynch Syndrome. Lancet Oncology. 2009;10:400-408.

Kupier RP, Vissers LELM, Venkatachalam R, Bodmer D, Hoenselaar E, Goossens M, Haufe A, Kamping E, Niessen RC, Hogevorst FBL, Gille JJP, Redeker B, Tops CMJ, van Gijn ME, van den Ouweland AMW, Rahner , Steinke V, Kahl P, Holinski-Feder E, Morak M, Kloor M, Stemmler S, Betz B, Hutter P, Bunyan DJ, Syngal S, Culver JO, Graham T, Chan TL, Nagtegaal ID, van Krieken JH, Schackert HK, Hoogerbrugge N, van Kessel AG, Ligtenberg MJL. Recurrence and Variability of Germline EPCAM Deletions in Lynch syndrome. Human Mutation. 2011;32:407-414.

Kwon JS, Sun CC, Peterson SK, White KG, Daniels MS, Boyd-Rogers SG, Lu KH. Costeffective Analysis of Prevention Stratgies for Gynecologic Cancers in Lynch Syndrome. Cancer. 2008;113:326-335.

Lancaster JM, Powell CB, Kauff ND, Cass I, Chen LM, Lu KH, Mutch DG, Berchuck A, Karland BY, Herzog TJ. Society of Gynecologic Oncologists Education Committee Statement on Risk Assessment for Inherited Gynecologic Cancer Predispositions. Gynecology Oncology. 2007;107:159-62.

Ligtenberg MJ, Kuiper RP, Chan TL, Goossens M, Hebeda KM, Voorendt M, Lee TYH, Bodmer D, Hoenselaar E, Hendriks-Cornelissen SJB, Tsui WY, Kong CK, Brunner HG, van Kessel AG, Yuem ST, van Krieken JH, Leung SY, Hoogerbrugge N . Heritable Somatic Methylation and Inactivation of MSH2 in Families with Lynch Syndrome due to Deletion of the 3' Exons of TACSTD1. Nature Genetics. 2009;41:112-7.

Lin KM, Shashidharan M, Ternent CA, Thorson AG, Blatchford GT, Christenson MA, Lanspa SJ, Lemon SJ, Watson P, Lynch H. Colorectal and Extracolonic Cancer Variations in MLH1/MSH2 Hereditary Nonpolyposis Colorectal Cancer Kindreds and the General Population. Diseases of the Colon E Rectum. 1998;41:428-33.

Lindor NM, Petersen GM, Hadley DW, Kinney AY, Miesfeldt S, Lu KH, Lynch P, Burke W, Press N. Recommendations for the Care of Individuals with an Inherited Predisposition to Lynch Syndrome: A Systematic Review. JAMA. 2006;296:1507-17.

Lindor NM, Rabe K, Petersen GM, Haile R, Casey G, Baron J, Gallinger S, Bapat B, Aronson M, Hopper J, Jass, J, LeMarchand L, Grove J, Potter J, Newcomb P, Terdiman JP, Conrad P, Moslein G, Goldberg R, Ziogas A, Anton-Culver H, de Andrade M, Siegmund K, Thibodeau SN, Boardman LA, Seminara D. Lower Cancer Incidence in Amsterdam-I Criteria Families without Mismatch Repair Deficiency: A Familial Colorectal Cancer Type X. JAMA. 2005;293:1979-1985.

$\mathrm{Lu} \mathrm{KH}$, et al. A Prospective, Multicenter Randomized Study of Oral Contraceptive versus Depo-Provera for the Prevention of Endometrial Cancer in Women with Lynch Syndrome. SGO 2010; Abstract 6.

Lu KH, Dinh M, Kohlmann W, Watson P, Green J, Syngal S, Bandipalliam P, Chen LM, Allen B, Conrad P, Terdiman J, Sun C, Daniels M, Burke T, Gershenson DM, Lynch H, Lynch P, Broaddus RR. Gynecologic Cancer as a "Sentinel Cancer" for Women 
with Hereditary Nonpolyposis Colorectal Cancer Syndrome. Obstetrics \& Gynecology. 2005:105:569-74.

Lu KH, Schorge JO, Rodabaugh KJ, Daniels MS, Sun CC, Soliman PT, White KG, Luthra R, Gershenson DM, Broaddus RR . Prospective Determination of Prevalence of Lynch Syndrome in Young Women with Endometrial Cancer. Journal of Clinical Oncology. 2007;25(33):5158-5164.

Lynch HT \& de la Chapelle A. Genomic Medicine: Hereditary Colorectal Cancer. NEJM. 2003;348:919- 32.

Lynch HT, Harris RE, Lynch PM, Guirgis HA, Lynch JF, Bardwil WA. Role of Heredity in Multiple Primary Cancer. Cancer. 1977;40:1849-54.

Lynch HT, Lynch PM, Lanspa SJ, Synder CL, Lynch JF, Boland CR. Review of the Lynch Syndrome: History, Molecular Genetics, Screening, Differential Diagnosis, and Medicolegal Ramifications. Clinical Genetics. 2009;76:1-18.

Masuda K, Banno K, Yanokura M, Kobayashi Y, Kisu I, Ueki A, Ono A, Asahara N, Nomura H, Hirasawa A, Susumu N, Aoki D. Relationship between DNA Mismatch Repair Deficiency and Endometrial Cancer. Molecular Biology International. 2011;(ID256063):1-6.

Mecklin JP and Jarvinen HJ. Clinical Features of Colorectal Carcinoma in Cancer Family Syndrome. Diseases of the Colon \& Rectum. 1986;29:160-4.

Meyer LA, Broaddus, RR, Lu KH. Endometrial Cancer and Lynch Syndrome: Clinical and Pathologic Considerations. Cancer Control. 2009;16:14-22.

Modica I, Soslow RA, Black D, Black D, Thornos C, Kauff N, Shia J. Utility of Immunohistochemistry in Predicting Microsatellite Instability in Endometrial Cancer. American Journal of Surgical Pathology. 2007;31:744-51.

NCCN Clinical Practice Guidelines in Oncology ${ }^{\mathrm{TM}}$ NCCN Guidelines Lynch Syndrome (Version 2.2011). National Comprehensive Cancer Network. Current version available at http:/ / www.nccn.org.

NCCN Clinical Practice Guidelines in Oncology ${ }^{\mathrm{TM}}$ Colorectal Cancer Screening (Version 2.2011). National Comprehensive Cancer Network. Current version available at http://www.nccn.org.

Niessen RC, Kleibeuker JH, Westers H, Jager POJ, Rozeveld D, Bos KK, Boersmavan-EK W, Hollema H, Sijmons RH, Hofstra RMW. PMS2 Involvement in Patients Suspected of Lynch Syndrome. Genes, Chromosomes \& Cancer. 2009;48:322-29.

Renkonen-Sinisalo L, Butzow R, Leminen A, Lehtovirta P, Mecklin JP, Jarvinen HJ. Surveillance for Endometrial Cancer in Hereditary Non-Polyposis Colorectal Cancer Syndrome. International Journal of Cancer. 2007;120:821-4.

Rumilla K, Schowalter KV, Lindor NM, Tomas BC, Mensink KA, Gallinger S, HolterS, Newcomb PA, Potter JD, Jenkins MA, Hopper JL, Long TI, Weisenberger DJ, Haile RW, Casey G, Laird PW, Merchand LL, Thibodeau SN. Frequency of Deletions of EPCAM (TACSTD1) in MSH2-associated Lynch Syndrome Cases. Journal of Molecular Diagnostics. 2011;13-93-99.

Senter L, Clendenning M, Sotamaa K, Hempel H, Green J, Potter JD, Lindblom A, Lagestedt K, Thibodeau SN, Lindor NM, Young J, Winship I, Dowty JG, White DM, Hopper JL, Baglietto L, Jenkins MA, de la Chapelle A. The Clinical Phenotype of Lynch Syndrome due to Germ-Line PMS2 Mutations. Gastroenterology. 2008;135(2):419-28. 
Schmeler KM, Lynch HT, Chen LM, Munsell MF, Soliman PT, Clark MB, Daniels MS, White KG, Boyd- Rogers SG, Conrad PG, Yang KY, Rubin MM, Sun CC, Slomovitz BM, Gershenson DM, Lu KH. Prophylactic Surgery to Reduce the Risk of Gynecologic Cancers in the Lynch Syndrome. NEJM. 2006;354:261-69.

Stoffel E, Mukherjee B, Raymond VM, Tayob N, Kastrinos F, Sparr J, Wang F, Bandipalliam P, Syngal S, Gruber SB. Calculation of Risk of Colorectal and Endometrial Cancer among Patients with Lynch Syndrome. Gastroenterology. 2009;137:1621-7.

Umar A, Boland CR, Terdiman JP, Syngal S, de la Chapelle A, Ruschoff J, Fishel R, Lindor NM, Burgart LJ, Hamelin R, Hamilton SR, Hiatt RA, Jass J, Lindblom Annika, Lynch HT, Peltomaki P, Ramsey SD, Rodriguez-Bigas MA, Vasen HFA, Hawk ET, Barrett JC, Freedman AN, Srivastava S. Revised Bethesda Guidelines for Hereditary Nonpolyposis Colorectal Cancer (Lynch Syndrome) and Microsatellite Instability. Journal of the National Cancer Institute. 200496:261-68.

van den Bos M, van den Hoven M, Jongejan E, van der Leij F, Michels M, Schakenraad S, Aben K, Hoogerbrugge N, Ligtenberg M, van Krieken JH. More Differences Between HNPCC-related and Sporadic Carcinomas From the Endometrium as Compared to the Colon. American Journal of Surgical Pathology. 2004;28:706-11.

Vasen HFA, Hendriks Y, de Jong AE, van Puijenbroek M, Tops C, Brocker-Vriends AHJT, Wijnen JTh, Morreau H . Identification of HNPCC by Molecular Analysis of Colorectal and Endometrial Tumors. Disease Markers. 2004;20:207-13.

Vasen HF, Mecklin JP, Meera KP, Lynch HT. The International Collaborative Group on Hereditary Nonpolyposis Colorectal Cancer (ICG-HNPCC). Diseases of the Colon $\mathcal{E}$ Rectum. 1991;34:424-425.

Vasen HF, Watson P, Mecklin JP, Lynch HT. New Clinical Criteria for Hereditary Nonpolyposis Colorectal Cancer (HNPCC, Lynch Syndrome) Proposed by the International Collaborative Group on HNPCC. Gastroenterology. 1999;116:1453-6.

Vasen HF, Watson P, Mecklin JP, Jass JR, Green JS, Nomizu T, Muller H, Lynch HT. The Epidemiology of Endometrial Cancer in Hereditary Nonpolyposis Colorectal Cancer. Anticancer Research. 1994;14(4B):1675-1678.

Vasen HF, Adbirahman M, Brohet R, Langers AM, Kleibeuker JH, van Kouwen M, Koomstra JJ, Boot H, Cats A, Dekker E, Sanduleanu S, Poley JW, Hardwick JC, de Vos Tot Nederveen Cappel Wh, van der Meulen-de Jong AE, Tan TG, Jacobs MA, Mohamed FL, de Boer SY, van de Meeberg PC, Verhulst ML, Salemans JM, van Bentem N, Westerveld BD, Vecht J, Nagengast FM. One to 2-year Surveillance Intervals Reduce the Risk of Colorectal Cancer in Families with Lynch Syndrome. Gastroenterology. 2010;138:2300-06.

Watson P, Butzow R, Lynch HT, Lynch HT, Mecklin J-P, Jarvinen HJ, Vasen HFA, Madrensky L, Fidalgo P, Bernstein I, International Collaborative Group on HNPCC . The Clinical Features of Ovarian Cancer in Hereditary Nonpolyposis Colorectal Cancer. Gynecology Oncology. 2001;82:223-8.

Wei K, Kucherlapati R, Edelmann W. Mouse Models for Human DNA Mismatch-Repair Gene Defects. Trends in Molecular Medicine. 2002;8(7):346-353.

Weissman SM, Bellcross C, Bittner CC, Freivogel ME, Haidle JL, Kaurah P, Leininger A, Palaniappan S, Steenblock K, Vu TM, Daniels MS. Genetic Counseling Considerations in the Evaluation of Families for Lynch Syndrome-A Review. Journal of Genetic Counseling. 2011;20:5-19. 
Westin SN, Lacour RA, Urbauer DL, Luthra R, Bodurka DC, Lu KH, Broaddus RR. Carcinoma of the Lower Uterine Segment: A Newly Described Association with Lynch Syndrome. Journal of Clinical Oncology. 2008;26:5965-71.

Whelan AJ, Babb S, Mutch DG, Rader J, Herzog TJ, Todd C, Ivanovich JL, Goodfellow PJ. MSI in Endometrial Cancer: Absence of MLH1 Promoter Methylation is Associated with Increased Familial Risk for Cancers. International Journal of Cancer. 2002;99:697704 .

Winawer S, Fletcher R, Rex D, Bond J, Burt R, Ferrucci J, Ganiats T, Levin T, Woolf S, Johnson D, Kirk L, Litin S, Simmang C. Colorectal Cancer Screening and Surveillance: Clinical Guidelines and Rationale-Update Based on New Evidence. Gastroenterology. 2003;124:544-60. 


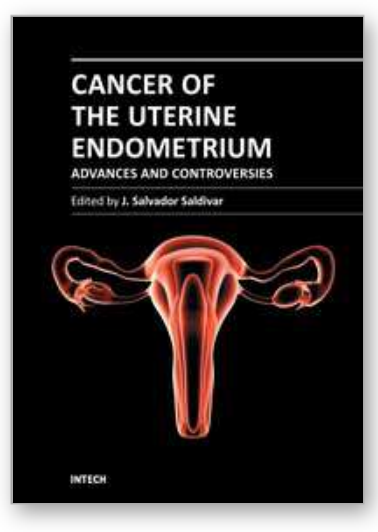

\author{
Cancer of the Uterine Endometrium - Advances and Controversies \\ Edited by Dr J.S. Saldivar
}

ISBN 978-953-51-0142-0

Hard cover, 182 pages

Publisher InTech

Published online 29, February, 2012

Published in print edition February, 2012

The book Cancer of the Uterine Endometrium - Advances and Controversies brings together an international collaboration of authors who share their contributions for the management of endometrial carcinoma. The scope of the text is not basic, but rather aims to provide a comprehensive and updated source of advances in the diagnosis and therapeutic strategies in this field of gynecologic cancer. Each section in the book attempts to provide the most relevant evidence-based information in the biology and genetics, modern imaging, surgery and staging, and therapies for endometrial cancer. It is hoped that future editions will bring additional authors to contribute to this endeavor. To this end, it is our patients who will benefit from this work.

\title{
How to reference
}

In order to correctly reference this scholarly work, feel free to copy and paste the following:

J. Salvador Saldivar (2012). Hereditary Endometrial Carcinoma, Cancer of the Uterine Endometrium Advances and Controversies, Dr J.S. Saldivar (Ed.), ISBN: 978-953-51-0142-0, InTech, Available from: http://www.intechopen.com/books/cancer-of-the-uterine-endometrium-advances-and-controversies/hereditaryendometrial-carcinoma

\section{INTECH}

open science | open minds

\section{InTech Europe}

University Campus STeP Ri

Slavka Krautzeka 83/A

51000 Rijeka, Croatia

Phone: +385 (51) 770447

Fax: +385 (51) 686166

www.intechopen.com

\section{InTech China}

Unit 405, Office Block, Hotel Equatorial Shanghai

No.65, Yan An Road (West), Shanghai, 200040, China

中国上海市延安西路65号上海国际贵都大饭店办公楼 405 单元

Phone: +86-21-62489820

Fax: +86-21-62489821 
(C) 2012 The Author(s). Licensee IntechOpen. This is an open access article distributed under the terms of the Creative Commons Attribution 3.0 License, which permits unrestricted use, distribution, and reproduction in any medium, provided the original work is properly cited. 